\title{
Muslim Teachers Perspectives on Students Hedonism Behaviors
}

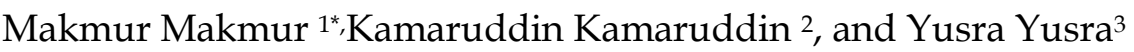 \\ ${ }^{1}$ Islamic Education Department, Postgraduate, Institut Agama Islam Negeri Palu \\ 2 Islamic Education Department, Postgraduate, Institut Agama Islam Negeri Palu \\ ${ }^{3}$ Islamic Education Department, Postgraduate, Institut Agama Islam Negeri Palu
}

\begin{abstract}
The aim of this study is to The aim of this paper is to discusse Muslim teachers perspectives on students hedonism behaviors at Senior High School Poso. This study used qualitative method in which the data was gathered through direct observation, in-depth interview with students' parents, and written material. The results of the study concluded that many students has bad behavior such as consumptive, individualistic, selfish, lazy, irresponsible, wasteful, undisciplined in time, lying, disrespectful of time, shouting, likes to scold, likes to curse, and likes to fight. Besides that, students also like to annoy classmates, like to skip school, and disrespect teachers. The Islamic Religious Education teacher at the school views hedonistic behavior as behavior that can lead students to behavior that exceeds boundaries. Meanwhile, this behavior is very disliked by Allah and His Messenger, so that Islamic Religious Education teachers and stakeholders are expected to prevent hedonistic behavior among students so it does not damage their future.
\end{abstract}

ARTICLE

INFORMATION

\section{Keywords:}

Muslims teachers, hedonism, behaviour, students 


\section{Introduction}

Whereas Islamic Religious

Education is a collection of Islamic religious subject matter, namely: Aqidah Akhlak, Fiqh, Islamic Cultural History, Qur'an Hadith and Arabic Language, but Arabic is now included in the family of language subjects, these subjects are very important to be studied by Muslim students. According to Azra, as quoted by the FIP-UPI Education Science Development Team, it was revealed that Islamic Religious Education (PAI) at every level has an important position in the national education system to create students who are faithful and devoted and have noble character. ${ }^{1}$ As quoted by Muhaimin, Buchori considers that Religious Education, especially Islamic Religious Education, is still failing. This failure is due to the fact that this educational practice only pays attention to the cognitive aspects of the growth of awareness of religious values, and ignores the development of affective and psychomotor aspects, namely the willingness and determination to practice the values of religious teachings. ${ }^{2}$

Behavior is all forms of human actions, behavior including rules regarding attitudes or behavior in our environment according to the habits of that place. Including politeness in behaving or speaking. Behavior can be described on the attitude or behavior of

1 Tim Pengembang Ilmu Pendidikan FIP-UPI, Ilmu dan Aplikasi Pendidikan Bagian III, (Jakarta : Grasindo, 2007), 6.

2 Muhaimin, Pengembangan Kurikulum Pendidikan Agama Islam, (Jakarta: Raja Grafindo Persada, 2007), 23. a person which is implemented in everyday life. Behavior can also be defined as an attitude that shows the willingness and ability of a person consciously to comply with the provisions and norms of life that apply in a community group or organization. ${ }^{3}$ Behavior also includes everything related to human actions that is positive or negative. Whereas hedonism is one of the behaviors that humans have where this trait is more likely to enjoy the life of this world without limits and rules, in other words that the pleasures of the world are essential pleasures, by which humans must enjoy them at will regardless of the rules that Allah has sent down. .

Hedonistic behavior is one of the theories that emerged by the results of human interpretation, this behavior appeared around the year 355-433 BC. The name of the originator of this theory is Aristippos of Kyrene, he is a student of Socrates. Aristippos said that what is really good for humans is pleasure and / or pleasure. He emphasized that pleasure should be understood as actual pleasure, not pleasure from the past and pleasures in the future. Good happiness or enjoyment in its true sense is pleasure here and now. According to Aristippos pleasure or pleasure is only material, actual and individual. Pleasure also needs to be limited to pleasures that are

3 Kurniati, Kurniati, Nurdin, Nurdin, \& Nurasmawati, Nurasmawati. (2020). Improving Students' Cognitive and Affective Domains Students through Fostering Teacher Development International Journal of Contemporary Islamic Education, 2(2), 56-70.

e-ISSN: 2715-4572

p-ISSN: 2716-1439 
easily attained, not those that are pursued with hard work. ${ }^{4}$

This behavior is very popular and is favored by anyone who does not think about the afterlife. Islam does not prohibit living comfortable or happily, even Islam recommends that its followers try to enjoy the life of this world, as long as it does not violate the rules that exist in Islam itself. The hearts and minds of adolescents among the Muslim community seem to have been wrapped and bound by hedonistic behavior, to the point that they forget about their obligations as adherents of the Islamic religion.

The Muslim Ummah today, especially the majority of students, are possessed by hedonistic behavior starting from adolescents, adults and even some parents, they prefer to make events that have less benefit than the harm, such as entering singing cafes by paying 35,000 per hour. This cannot be denied, let alone in urban areas and has even reached rural areas, especially among adolescents who are still in high school (SMA), this is one small example of the hedonistic behavior currently possessed by our nation's young generation.

High school students still have a very high level of instability, so whatever they see and hear is sometimes followed immediately without paying attention and considering the impact $^{5}$. Based on

4 K. Bertens, Etika, (Jakarta: Gramedia Pustaka Utama, 2002), 236.

5 Evita, Evita, Syahid, Ahmad, \& Nurdin, Nurdin. (2019). Understanding Students' Learning Outcomes Differences Through the preliminary observations at State Senior High School 4 Poso, the researcher saw various kinds of hedonistic behavior that students had.

\section{Literature Review}

\subsection{Hedonistic Behaviour}

Behavior in Islam is called morals, Islamic personal morals can be defined as a form of character that is inherent and implemented by Muslims and is based on the source of Islamic teachings. Meanwhile, according to Imam al-Ghazali as quoted by Wahyudi stated that: In fact, morality is a strong will about something that is done repeatedly so that it becomes a cultured custom that leads to goodness, and in fact morals are inherent in the soul in the form of actions and behavior. So something is said to be moral if the behavior is attached to someone because it has been done repeatedly or continuously so that it becomes a habit.

Behavior or morals cannot be separated from Aqidah and Shari'ah. Therefore, morals are patterns of behavior that accumulate aspects of belief and obedience so that they are reflected in good behavior. Morals are behaviors that can appear (seen) clearly, both in words and actions which are motivated by an impulse because of Allah. However, there are also many aspects related to mental attitudes or

Application of the Market Place Activity Type of Cooperative Learning Model and the Application of Conventional Learning Models International Journal of Contemporary Islamic Education, 1(1), 67-85. 
thoughts, such as morality, which is related to various aspects, namely patterns of behavior towards God, fellow humans, and patterns of behavior towards nature. ${ }^{6}$ Islamic morals can be said to be Islamic morals, which are morals that are derived from the teachings of Allah and the Prophet. This Islamic morality is an open deed so that it can be an indicator of a person whether a Muslim is good or bad. These morals are the fruit of true faith and sharia. Basically, this morality is closely related to human events, namely khaliq (creator) and creature (created). Rasulullah was sent to perfect human morals, namely to improve the relationship between the human being and the khaliq (Allah Ta'ala) and the good relationship between the creatures. ${ }^{7}$

A person's behavior is motivated by the attitudes that exist in the individual concerned. LaPiere as quoted by Bimo said that behavior will be separated from one's attitude. Meanwhile, according to Meyrs, as quoted by Bimo, that behavior is something that will be subject to a lot of influence from the environment. ${ }^{8}$

Meanwhile, hedonism in the Big Indonesian Dictionary means an understanding that considers material

${ }^{6}$ Rusli, R., Hasyim, M. S., \& Nurdin, N. (2021). A New Islamic Knowledge Production And Fatwa Rulings: How Indonesia's Young Muslim Scholars Interact With Online Sources. Journal of Indonesian Islam, 14(2), 499-518.

7 Syarifah Habibah, Akhlak dan Etika dalam Islam, Jurnal, Pesona Dasar, Vol. 1 No. 3, (2015), 74.

8 Bimo Walgito, Psikologi Sosial, (Yogyakarta: Andi Offset, 1987), 124. pleasure and enjoyment as the most important goal in life. The desire to be happy is one of the most important sources. According to Epicurus, happiness is not only obtained from a pleasant life but also from suffering, in contrast to his followers. Armstrong said as quoted by Novita that the behavior of hedonism is a lifestyle whose activities are to seek the pleasures of life, such as spending time outside the house, playing a lot, being happy in city crowds, happy to buy expensive things they like, and wanting to be the center of attention. The life behavior of one individual to another will be different. Life behavior shows how a person regulates his personal life, community life, behavior in public, and attempts to distinguish his status from others through social symbols. ${ }^{9}$

Hedon (followed by -ism; Hedonism) comes from Greek: hēdonē, which means pleasure, joy, pleased, satisfaction. Hedonism describes a variety of thoughts that make "pleasure" the center of control. Hedonism in general can conclude that "pleasure is the highest good" or in other terms "whatever brings pleasure is true." Furthermore, Hedonism can be defined as a doctrine that adheres to the assumption that human habits are motivated by a desire for pleasure and avoid suffering.

Furthermore, according to Susanto, hedonism is shown by

9 Novita Trimartati, "Studi Kasus Tentang Gaya Hidup Hedonisme Mahasiswa Bimbingan dan Konseling Universitas Ahmad Dahlan", Jurnal, Psikopedagogia, Vol. 3 No.1, (2014), 21. 
preferring to spend spare time in a relaxed place such as a cafe. Having fun in a cafe is not always synonymous with drinking alcohol but is more about spending free time or relaxing but can also represent a status symbol. Hedonic is a behavior that combines the need for self-expression and group expectations of a person in acting based on prevailing norms. Therefore, it is widely known the kinds of behavior that are developing in today's society, for example hedonic behavior, metropolis living behavior, global living behavior and so on. This kind of life behavior holds that material pleasure and enjoyment are the main goals of life. For adherents of this belief, having fun, attending parties are the main purpose of life, whether it's fun for others or not. Because they think that life is only once, so they feel they want to enjoy life more. ${ }^{10}$

According to Nugroho, life behavior is broadly defined as a way of life that is identified by how humans spend their time, what they think about themselves and also the world around them. Therefore, it is related to actions and behavior from birth. In development, each individual has different hedonistic behavior. Every human being has their own characteristics in pouring out a penchant for behaving in a hedonistic life. According to Rahardjo and Silalahi, some characteristics of hedonistic life behavior are generally remaining and living in big cities, where this is of course related to opportunities for access

10 Susanto, Potret-Potret Gaya Hidup Metropolis, (Jakarta: Kompas, 2001), 33. to information, will clearly affect lifestyle, come from wealthy circles and have a lot of money because of the large amount of material needed. as a support for living behavior, following fashion developments in fashion magazines in order to find out the latest fashion developments that are easy to follow, generally have a fashionable appearance, are trendy and pay great attention to appearance. ${ }^{11}$ Hedonism is a thought pattern which states that maximizing enjoyment is the best and most preferred thing in human life in this world. The term hedonism is a combination of two words, namely: hedone and ism. The first word, hedone, is a Greek term which means pleasure or happiness. ${ }^{12}$ The Oxford English Dictionary defines hedonism as a doctrine or ethical theory which states that happiness is the stage of the highest good. ${ }^{13}$

This second definition is in line with John David Garcia's view which states that in a culture of hedonism, fun / happiness and joy get the highest points. He explained that hedonism is: "A sense of values which gives the highest value to pleasure and happiness. Hedonism represents the pursuit of happiness to the exclusion of awareness.

11 W. Rahardjo dan Y.B. Silalahi, Perilaku Hedonisme Pada Pria Metroseksual Serta Pendekatan dan Strategi yang Digunakan untuk Mempengaruhinya, (Jakarta: Universitas Gunadarma Pesat, 2007), 34.

12 Jonathan Ree \& J.O. Urmson, The Concise Encyclopedia of Western Philosophy, Routledge, (London dan New York, 2005), 152.

13 J.A. Simpson and E.S.C. Weiner, The Oxford English Dictionary, (Oxford : Clarendon Press, 1989), 98. 
A hedonists seeks to maximize the happiness above all else ". ${ }^{14}$

Meaning: The sense of value that gives the highest value to pleasure and happiness. Hedonism pursues happiness at the expense of consciousness. An ideology that seeks to maximize happiness above all else.

Teaching about hedonistic behavior is to equate goodness with pleasure. So all happiness and pleasures physically always bring good. This view of life teaches followers or those who are ready to follow it that worship of the happiness and pleasures of the world must be pursued, and that is the most essential purpose of life for humans. This view of life is what nowadays and almost all human beings like it and make it a benchmark in life behavior. Thus the notion of hedonism itself means a thought that makes the goal of life is material pleasure. A pleasure that satisfies the soul of every human being. Epicurus argued that material enjoyment is the main goal in life. His philosophy focuses on morals that provide inner peace. Hedone (pleasure or enjoyment) is obtained by satisfying one's desire. Humans must be able to choose their desires in order to achieve deep satisfaction. Hedonism which only seeks material pleasures for the sake of soul satisfaction is not perfect until someone is farther away from the spiritual life which is considered to be restricting humans. ${ }^{15}$ Hedonism is a cultural manifestation that always tries

14 John David Garcia, The Moral Society, (New York: The Julain Press Inc, 1971), 330.

15 Susanto, Potret-Potret Gaya Hidup Metropolis, (Jakarta: Kompas, 2003), t.h to avoid difficulties, seek and produce conveniences. Where the offer is the satisfaction of desire, wish, and lust. ${ }^{16}$

According to Epicurus, it is as quoted by Cahyaningrum that the highest pleasure is tranquility (welfare and freedom from fear) which can only be obtained from knowledge, friendship, virtuous and temperate life. Recognizing the existence of feelings of simple pleasures (enjoyment of simple pleasures), and defines pleasure as something that must be far from bodily desires. This hedonic behavior in general is not usually released from the popular culture that accompanies the dynamics of life, including the world of literature. ${ }^{17}$

According to Salam, the principle of hedonic life behavior assumes that everything will be considered good if it is in accordance with the pleasure to be obtained. Other notions of hedonic life behavior are also expressed by Wells and Tiᄀgert in Engel, Blackwell and Miniard, explaining that hedonic behavior is a person's lifestyle as a process of using money and time that is owned which is expressed in the activities, interests, and opinions concerned. This is manifested in certain things such as fashion, food, luxury items, places to gather and always wanting to be the center of attention. People who adhere to hedonist behavior often spend time outside the home, such

\footnotetext{
${ }^{16}$ Ibid., 48.

17 Cahyaningrum Dewojati, Wacana Hedonisme dalam Sastra Populer Indonesia, (Yogyakarta: Pustaka Pelajar, 2010), 16.

e-ISSN: 2715-4572

p-ISSN: 2716-1439
} 
as malls and cafes ${ }^{18}$. Hedonic life behavior that emphasizes fun, raises the assumption that life-oriented behavior is exaggerated, while in terms of religiosity, hedonic life behavior is not justified because according to Chatijah and Purwadi one of the causes of increased behavior hedonic life in adolescence is due to a decline in faith. If someone experiences a decline in faith, he tends to do things that are prohibited by religion. One of the prohibitions of religion is being profligate or being extravagant. ${ }^{19}$

According to Glock and Stark, as quoted by An $\neg$ cok and Suroso, it is said that basically a religious person will always try to do good, not only for himself but also for others. Religiosity is a symbol of a system of beliefs, values, and behaviors that focus on various worldly problems whose overall meanings are summed up in an essential belief. Glock and Strak, as quoted by Ancok and Suroso, suggest that there are several dimensions of religiosity, namely belief, ritual, practice, knowledge and experience. Based on the dimension of belief, people with a high level of religious belief will behave consequently with their religious teachings in socializing with society. But besides that, the results of Ernest Harms' research as quoted by Jalaluddin revealed that adolescents are more concerned with

18 Ardilla Saputri dan Risana Rachmatan, Religiusitas Dengan Gaya Hidup Hedonisme: Sebuah Gambaran Pada Mahasiswa Universitas Syiah Kuala, Jurnal Psikologi, Vol. 12 No.2, (2016), 60.

19 Ibid, 60. personal pleasure than matters of religiosity. ${ }^{20}$

Another dimension of religiosity, according to Glock and Stark, as quoted by Ancok and Suroso, said that what can influence hedonic life behavior is the dimension of practice. This dimension discusses the extent to which individual behavior is motivated by the teachings of his religion in social life, so that if students have good religious practice, then these students will show social behavior in accordance with the teachings of their religion. This is supported by the research conducted by Rocca, as quoted by Mulia, which reveals that someone who has high religiosity is more committed to the teachings of his religion so that he has a relatively low desire to follow life behaviors that only concern pleasure. Based on this statement, it is clear how religiosity is one of the aspects that can reduce the level of hedonic life behavior.

Hedonic behavior forms a human mental attitude that is fragile, easily discouraged, does not want to be bothered, always wants to take shortcuts, does not live concerned, and does not want to work hard. Someone who is trapped in hedonic life behavior will take part in the fun. As for things that would overwhelm him, he avoided it. They doesn't want to care how their parents work hard day and night, meanwhile they can only hang out at the mall, hang out with wealthy people, always choosing expensive items even though using relatively cheap items actually can. What is attached to them

${ }^{20} \mathrm{Ibid}, 60$.

e-ISSN: 2715-4572

p-ISSN: 2716-1439 
must always seem luxurious and elegant. Hedonic behavior is synonymous with glamorous, funloving, and fun ways of living.

Hedonic life behavior will lead a person to a mental attitude that does not want to care and is sensitive to the diversity of life, has no sensitivity to the difficulties of other people's lives. In short, hedonistic life behavior gives birth to humans with dull social attitudes, giving birth to asocial types of people. Even though life in this world is just a joke and a joke.

Human hedonists clearly ignore and do not want to care about religious teachings. Religion for hedonists is nothing more than clothes that are ready to take off and leave at any time, then put on again whenever they like. Religious messages are nothing more than advertisements hitching a ride, there is no desire to understand, and let alone practice them. Hedonism has dragged them into a heretical mindset, namely how to make them able to achieve pleasure and utility even though they are contrary to the teachings of Islam. They are spiritually empty because they consider religious teachings to be a barrier to the fulfillment of worldly pleasures. One strong trigger for the ferocity of hedonism today is the contemporary way of life with technological product knick-knacks. People want to own things like sophisticated cellphones, are ashamed if they can't buy a car, feel inferior to their neighbors if they don't have a large television. The shame of the hedonists for not being able to fulfill what they want, not the shame of behaving in a deviant manner. ${ }^{21}$

Hedonistic behavior is included in one of the humanistic streams, the flow of humanity assumes that humans are born into this world with lust and destructive desires, in other words that humans are only one of the things in this world that can be made at will. If they are greedy and want to dominate other humans, want to get as much pleasure as possible in this world, they should not be blamed because it is instinct. Likewise, if humans are cheated, it is okay to be raped, because humans are just objects like other things. Can be shaped at will we. The school of humanity considers humans to be special creatures who have the will and freedom. Can do according to his own will without submitting to outside powers.

Adherents of hedonist behavior are too confined to the flow of humanity and what is even more heartbreaking is that the generation of the Muslim nation is also confined, Islam really values freedom, but freedom has limits, Hasan Langgulung said that unlimited freedom will turn to anarchy and then to destruction. Human freedom is not freedom in vain. Humans are not allowed to use their freedom to endanger themselves and others. Based on this view, humans should not kill themselves according to their own will, because life is a gift from God Almighty, given to humans to enjoy and endeavor

21

Bakri,

http://aceh.tribunnews.com/2018/04/06/Aga ma-dan-Hedonisme, diakses, 03 Januari 2019.

e-ISSN: 2715-4572

p-ISSN: 2716-1439 
to protect and maintain until the end of their lives.

\subsection{Types Of Hedonism Behavior}

Hedonism in society is divided into three (3) types, namely:

A. Psychological Hedonism

Assume that humans are created out of the way to desire pleasure. Instinctively, humans do have the nature of avoiding pain and suffering. Psychological hedonism is the doctrine that humans always do something that is thought to give them the greatest pleasure. This doctrine became known as the hedonism of egoistic psychology.22

B. Evaluative Hedonism

Evaluation is an assessment ${ }^{23}$. while hedonism is a notion that assumes that pleasure is the truth in this world. This means that pleasure is what a person wants and pursues. In the concept of evaluative hedonism, only pleasure is valuable and pain or displeasure is something that is disappointing or is also considered something that is not worth feeling.

\section{Rationalizing Hedonism}

Rational is something according to thoughts and considerations with logical reasons, according to a healthy mind or according to common sense ${ }^{24}$. So rationalizing hedonism is someone looking for pleasure but understands the

22 G.H.R. Parkinson et al. (Eds.), An Encyclopaedia of Philosophy, (London: Routledge, 1996), 894.

23 Departemen Pendidikan Nasional, Kamus Bahasa Indonesia, (Jakarta: Pusat Bahasa, 2008), 400.

24 Ibid, 1173. consequences. For example, someone takes drugs to seek pleasure and release the burden of problems for a moment. But those users know that it is bad for health and can also bring it into the realm of crime.

\section{Methodology}

This study uses a qualitative approach with the object of research is a high school in Palu. In this study, the writer took one of the high schools to be the case.

In the implementation of this research, the researcher chose Poso 4 State Senior High School as a research location. Researchers chose the location of SMAN 4 Poso because the students were diverse and had a hedonistic lifestyle. Thus, researchers have the opportunity to understand the opinions of teachers on the lifestyle of these students.

The use qualitative methods in this study with several considerations. First, adjusting qualitative methods is easier when dealing with multiple realities. Second, it can directly present the nature of the relationship between researchers and informants ${ }^{25}$. Third, this method is more sensitive and adaptable to the many sharpening of the common direction and the patterns of values encountered. ${ }^{26}$

${ }^{25}$.Nurdin, Nurdin, Stockdale, Rosemary, \& Scheepers, Helana. (2014a). Coordination and Cooperation in E-Government: An Indonesian Local E-Government Case The Electronic Journal of Information Systems in developing Countries, 61(3), 1-21.

26Nurdin, Nurdin. (2018). Institutional Arrangements in E-Government Implementation e-ISSN: 2715-4572 p-ISSN: 2716-1439 
Data were collected using observation techniques, in-depth interviews with the school principla and teachers from the school, and from shared written documents. ${ }^{27}$ While the data analysis is done using reduction and verification techniques with various data sources. ${ }^{28}$ The reduced data is then analyzed by claiming to the theoretical concepts used in this study.

\section{Result and Discussion}

\subsection{Hedonistic Behavior of Students in Senior High Schools}

Humans were indeed created by Allah SWT to enjoy what is in this world, with the creation of this world and its contents, humans are given the freedom to produce, use / enjoy and share what Allah has created, logically, what Allah created is prohibited. Again there are prohibitions for humans, but it needs to be realized that even though Allah SWT created this world and its contents for humans to use for their survival, humans must also be aware that all of this is a test for or enjoying

and Use: A Case Study From Indonesian Local Government. International Journal of Electronic Government Research (IJEGR), 14(2), 44-63. doi: 10.4018/ijegr.2018040104

${ }^{27}$.Nurdin, Nurdin, Stockdale, Rosemary, \& Scheepers, Helana. (2014b, 6-9 Jan. 2014). The Role of Social Actors in the Sustainability of EGovernment Implementation and Use: Experience from Indonesian Regencies. Paper presented at the System Sciences (HICSS), 2014 47th Hawaii International Conference on System Science.

28 Nurdin, Nurdin, \& Aratusa, Zana Chobita. (2020). Benchmarking level interactivity of Indonesia government university websites. TELKOMNIKA Telecommunication, Computing, Electronics and Control, 18(2), 853-859. everything that has been created in this world does not necessarily have to be consumed at will, because after all the creator will still make rules, so that humans do not transcend the limits of the use of the creation of the owner of the world and its contents, with the creation of the world and its contents, there are many humans who live beyond the limit, even though Allah SWT has lowered the guidelines for life, namely Al-Quran then added with the hadith of the Prophet Muhammad. The contents of the two guidelines contain all aspects of the order of human life, even they have been well and neatly arranged, the goal is that humans continue to live according to the will of Allah SWT.

Hedonistic behavior or the behavior of human life that exceeds this limit cannot be denied, because humans have lust, with that passion humans sometimes forget that there are binding rules, which must be implemented in their daily life, with the drive of their desires that are also humans which tend to have hedonistic behavior. This hedonistic behavior existed since the time of the prophet Adam has existed and this has been practiced by his son, namely habil. Until now, the behavior of hedonism is growing and has many varieties and forms. Such as consumptive, individualistic, selfish, lazy, irresponsible, wasteful, corrupt and others.

Consumption is the most basic human activity. Consumption is interpreted in various ways, both broad and narrow. The meaning of narrow put forward by Mary Douglas and Baron Isherwood as quoted by Adlin reveals

e-ISSN: 2715-4572

p-ISSN: 2716-1439 
that consumption is the use of property rights that have material value, that is, depletes the value of the material itself 29 . This definition does not cover the whole of consumption as expressed by Piliang, as quoted by Adlin, suggesting the meaning of consumption broadly, namely the fact that people do not only consume material things but also consume non-material things, such as thoughts and ideas. When people think and come up with ideas repeatedly, that means that person is consuming nonmaterial consumption. ${ }^{30}$

Baudrillard explains that current consumption behavior is not only influenced by factors that are purely economic and based on rational choices, but there are cultural systems and systems of social meaning that are able to direct individual choices for a commodity. The same is the case with what was done by the informant, where in the quotation of the informant's statement above that he was willing to save for three years just to buy the motorbike he had dreamed of. ${ }^{31}$

\section{Consumptive}

According to Suhendi, the consumptive behavior of students at Poso 4 Public Senior High School has existed and developed since the family environment until they became students at Poso 4 Public Senior High School and its development is estimated to reach 75 percent, especially in shopping and

\footnotetext{
${ }^{29}$ A. Adlin, Resistensi Gaya Hidup Teori Dan Realitas, (Bandung: Jalasutra, 2006), 391.

30 Ibid,

31 J. P. Baudrillard, La Société de Consommation (Masyarakat Konsumsi), (Yogyakarta: Kreasi Wacana, 2011), 74.
}

consuming food. ${ }^{32}$ In line with that St. Chadijah Badau and Novita Andayani revealed that the development of the consumptive nature of the Poso 4 Public Senior High School students is estimated to reach 75 percent or more, especially in shopping for food and ready-to-drink drinks and others. ${ }^{33}$

From the explanation of the results of the interview, the authors concluded that the consumptive behavior of students at the Poso 4 Public Senior High School before they became students at the school was very dangerous because it had reached 75 percent, so for teachers of Islamic Religious Education subjects and stakeholders in the school is difficult to anticipate and prevent it, eating too much can also result in students being sleepy and lazy to learn, so that the material presented by the teacher in the learning process they cannot understand properly, while the main purpose of students coming to school is to learn.

2. Individualist

According to Suhendi, the individualistic behavior of students in Poso 4 State Senior High School has existed and developed since the family environment until they became students at the Poso 4 Public Senior High School and its development is estimated at

32Suhendi, Guru Mata Pelajaran Pendidikan Agama Islam Sekolah Menengah Atas Negeri 4 Poso, wawancara Penulis di Poso, 14 Desember 2019.

${ }^{33}$ St. Chadijah Badau dan Novita Andayani, Guru Mata Pelajaran Pendidikan Agama Islam Sekolah Menengah Atas Negeri 4 Poso, wawancara Penulis di Poso, 14 Desember 2019.

e-ISSN: $2715-4572$

p-ISSN: 2716-1439 
around five percent. $^{34}$ St. Chadijah Badau and Novita Andayani revealed that the development of the individualistic behavior of the Poso 4 Public Senior High School students is estimated to reach 5 percent or more, this trait has existed since they were in their family environment so that it is a congenital that they continue to apply in school. ${ }^{35}$

From the explanation of the results of the interview, the authors concluded that the individualistic behavior of the students at State Senior High School 4 Poso, the development is estimated at 5 percent, this trait has been owned by students since they were in the family environment so that these traits they continue to apply in school, this happens because the innate nature of the environment in which they have been involved, even though this individualistic behavior is strictly prohibited in Islam, because after all humans are social creatures, where humans need each other, and those who implement these characteristics are the majority of Muslim students.

3. Selfish

According to Suhendi, the selfish behavior of students in Poso 4 State Senior High School has existed and was formed from within the family until they became students at the Poso 4 Public Senior High School and its

\footnotetext{
${ }^{34}$ Suhendi, Guru Mata Pelajaran Pendidikan Agama Islam Sekolah Menengah Atas Negeri 4 Poso, wawancara Penulis di Poso, 14 Desember 2019.

${ }^{35}$ St. Chadijah Badau dan Novita Andayani, Guru Mata Pelajaran Pendidikan Agama Islam Sekolah Menengah Atas Negeri 4 Poso, wawancara Penulis di Poso, 14 Desember 2019.
}

development is estimated at around 3 percent. ${ }^{36}$ St. Chadijah Badau revealed that the development of the selfish behavior of the Poso 4 Public Senior High School students reached 8 percent. Meanwhile, Novita Andayani revealed that her development could reach 47 percent, this behavior they have since they are in their family environment. ${ }^{37}$

From the explanation of the results of the interview, the authors concluded that the selfish behavior of the students of State Senior High School 4 Poso, the development is estimated to reach more than 8 percent, the selfish behavior of these students has developed since they are still in their family environment, not only in their family environment, this trait can also develop because the community environment where they hang out, even their selfish behavior can also develop since they are in an elementary school or junior high school / equivalent. This selfish behavior should not be possessed by students, especially Muslims, because this trait is a trait possessed by the devil and his troops, if any of the Muslims have this characteristic, it means that he has been trapped by the tricks of the devil and his troops, this selfish behavior can also lead people to arrogant nature, as the devil's selfishness not to want to submit to the prophet adam as.

\footnotetext{
${ }^{36}$ Suhendi, Guru Mata Pelajaran Pendidikan Agama Islam Sekolah Menengah Atas Negeri 4 Poso, wawancara Penulis di Poso, 14 Desember 2019.

${ }^{37}$ St. Chadijah Badau dan Novita Andayani, Guru Mata Pelajaran Pendidikan Agama Islam Sekolah Menengah Atas Negeri 4 Poso, wawancara Penulis di Poso, 14 Desember 2019.

e-ISSN: 2715-4572

p-ISSN: 2716-1439
} 
4. Lazy

According to Suhendi, the lazy behavior of students in Poso 4 State Senior High School has existed and developed since the family environment until they became students at the Poso 4 Public Senior High School and its development is estimated at around 5 percent. ${ }^{38}$ St. Chadijah Badau revealed that the development of the lazy behavior of the Poso 4 Public Senior High School students reached 30 percent. Meanwhile, Novita Andayani revealed that her development can reach 75 percent, this behavior they have since their family environment. ${ }^{39}$

From the explanation of the results of the interview, the authors conclude that the lazy behavior of students at State Senior High School 4 Poso, its development is estimated to reach more than 30 percent, the lazy nature is influenced by the family and community environment, basically the family and community environment has a very big influence on character development. students, so that the good or bad of all student behavior is determined by their family and community environment ${ }^{40}$ or social environment, Islam hates lazy humans

${ }^{38}$ Suhendi, Guru Mata Pelajaran Pendidikan Agama Islam Sekolah Menengah Atas Negeri 4 Poso, wawancara Penulis di Poso, 14 Desember 2019.

${ }^{39}$ St. Chadijah Badau dan Novita Andayani, Guru Mata Pelajaran Pendidikan Agama Islam Sekolah Menengah Atas Negeri 4 Poso, wawancara Penulis di Poso, 14 Desember 2019.

${ }^{40}$ Rusli, R. (2020). The Role of Family in Preventing Social Conflict in Society From Islamic Perspectives. Hunafa: Jurnal Studia Islamika, 17(1), 108-122 from all aspects of life, even though the prophets and messengers sent by Allah SWT survive to carry out their mission and da'wah by making good use of time, like the prophet Daud as, the prophet ya'qub as, the prophet Muhammad saw and other prophets and messengers, people who are lazy certainly do not appreciate the time that Allah has given.

5. Less Responsible

According to Suhendi, the irresponsible behavior of students in Poso 4 Public Senior High School has existed and developed since the family environment due to a lack of guidance and guidance from parents until they become students at the Poso 4 Public Senior High School and its development is estimated at 10 percent. ${ }^{41}$ St. Chadijah Badau revealed that the development of the irresponsible nature of the Poso 4 Public Senior High School students reached 80 percent. Meanwhile, Novita Andayani revealed that the development can reach 38 percent, this behavior they have since their family and society where they live and socialize. ${ }^{42}$

From the explanation of the results of the interview, the authors concluded that the irresponsible behavior of students at State Senior High School 4 Poso, the development of which is estimated at more than 38 percent, the irresponsibility is influenced by the

${ }^{41}$ Suhendi, Guru Mata Pelajaran Pendidikan Agama Islam Sekolah Menengah Atas Negeri 4 Poso, wawancara Penulis di Poso, 16 Desember 2019.

${ }^{42}$ St. Chadijah Badau dan Novita Andayani, Guru Mata Pelajaran Pendidikan Agama Islam Sekolah Menengah Atas Negeri 4 Poso, wawancara Penulis di Poso, 16 Desember 2019.

e-ISSN: 2715-4572

p-ISSN: 2716-1439 
family and community environment where they carry out social interactions every day, the family environment and the community. has an important role in making children as the nation's generation with character, responsibility, noble character, because what students get in the family and community environment, of course they will apply in the school environment. This irresponsible behavior is also disliked by Allah, both in terms of being less responsible for oneself, other people, family, society, nation and State. All human beings are given responsibility by Allah Almighty and the responsibility that has been given will be held accountable, while the responsibilities given by fellow humans will also be accountable to the humans who give responsibility.

6. Wasteful

According to Suhendi, that the extravagant behavior of students in Poso 4 State Senior High School has existed and developed since the family environment, the cause is that their parents are on average capable (PNS / TNI / POLRI / Entrepreneurs) until they become students at State Senior High Schools 4 Poso and its development is estimated at 20 percent. ${ }^{43}$ St. Chadijah Badau revealed that the development of the extravagant behavior of the Poso 4 Public Senior High School students reached 40 percent. Meanwhile, Novita Andayani revealed that her development can reach

${ }^{43}$ Suhendi, Guru Mata Pelajaran Pendidikan Agama Islam Sekolah Menengah Atas Negeri 4 Poso, wawancara Penulis di Poso, 16 Desember 2019.
30 percent, this trait they have since their family environment, this happens because parents are too indulgent and follow the wishes of their children, which means that guidance from parents to live simply even though they have a lot of assets is very lacking. ${ }^{44}$

From the explanation of the results of the interview, the authors concluded that the extravagant behavior of students at State Senior High School 4 Poso, its development is estimated to reach more than 30 percent, this behavior is influenced by parents who do not foster their children to live simply, even parents are too indulgent and follow all their children's wishes so their children are accustomed to living in luxury which results in their extravagant nature which is inevitable and is still embedded in him, thus students whose parents are capable and have extravagant characteristics can influence students who are less fortunate and it cannot be denied, the most prominent extravagant behavior is 90 percent of students drive two wheels to school, even though if they can think well, then surely they will use the BUS that has been prepared by the Poso Regency government, in addition to reducing the risk of accidents, coming to school on time, money for fuel buyers can be obtained bung for his future, also avoid traffic police raids, because on average they do not wear helmets and do not have a driver's license.

7. No Time Discipline

${ }^{44}$ St. Chadijah Badau dan Novita Andayani, Guru Mata Pelajaran Pendidikan Agama Islam Sekolah Menengah Atas Negeri 4 Poso, wawancara Penulis di Poso, 16 Desember 2019.

e-ISSN: 2715-4572

p-ISSN: 2716-1439 
According to Suhendi, the undisciplined behavior of students in Poso 4 State Senior High School has existed and developed since the family environment and there is a lack of family attention, especially parents who do not apply the rules that have been agreed upon and given since registering their children and their development is estimated to reach 20 percent. ${ }^{45}$ St. Chadijah Badau revealed that the development of undisciplined behavior students of Poso 4 Public Senior High School reached 80 percent. Meanwhile, Novita Andayani revealed that the development can reach 25 percent, this characteristic is influenced by the family and community environment. 46

From the exposure to the results of the interview, the authors concluded that the time indiscipline behavior of students at State Senior High School 4 Poso is estimated to have reached more than 25 percent, the time undisciplined behavior naturally stems from the environment of family and society and or their peers, thus it can It is proven that every night on line 2 they stay up late until dawn or maybe at home they pretend to enter the room and then play the game, especially with the emergence of the PUBG game online, which causes them to wake up slowly to prepare themselves to come to school to study.

45Suhendi, Guru Mata Pelajaran Pendidikan Agama Islam Sekolah Menengah Atas Negeri 4 Poso, wawancara Penulis di Poso, 16 Desember 2019.

46St. Chadijah Badau dan Novita Andayani, Guru Mata Pelajaran Pendidikan Agama Islam Sekolah Menengah Atas Negeri 4 Poso, wawancara Penulis di Poso, 16 Desember 2019.
And during this research, the authors saw that most students had undisciplined behavior in time, such as when security gave 10 minutes of permission to go out to get books or other necessities at home, either walking or driving two wheels, they were sometimes slow 3, 4 and even 6 minutes. 8. Likes to lie

According to Suhendi, the lying behavior of students in Poso 4 State Senior High School has existed and developed since the family environment as well as the lack of family attention, especially parents who rarely advise them when they are lying and its development is estimated at 20 percent. $^{47}$ St. Chadijah Badau revealed that the development of lying behavior among Poso 4 Senior High School students reached 80 percent. Meanwhile, Novita Andayani revealed that the development can reach 25 percent, this behavior is influenced by the family and community environment. ${ }^{48}$

From the exposure to the results of the interview, the authors concluded that the lying behavior of the students of State Senior High School 4 Poso, the development is estimated to reach more than 25 percent, the lying behavior of course originates from the family and community environment and / or their peers, this can be proven when students

47Suhendi, Guru Mata Pelajaran Pendidikan Agama Islam Sekolah Menengah Atas Negeri 4 Poso, wawancara Penulis di Poso, 16 Desember 2019.

48St. Chadijah Badau dan Novita Andayani, Guru Mata Pelajaran Pendidikan Agama Islam Sekolah Menengah Atas Negeri 4 Poso, wawancara Penulis di Poso, 16 Desember 2019.

e-ISSN: 2715-4572

p-ISSN: 2716-1439 
commit violations or come to school late, they lie to the picket teacher when asked. And during this research, the authors saw that most of the students had lying behavior.

9. Loves to Swear

According to Suhendi, the behavior of berating students at Poso 4 State Senior High School has existed and developed since the family environment and there is a lack of family attention, especially parents who do not apply the rules that have been agreed upon and given since registering their children and their development is estimated at 20 percent. St. Chadijah Badau revealed that 80 percent of the students at Poso Public Senior High School 4 had an insulting behavior. Meanwhile, Novita Andayani revealed that the development can reach 25 percent, this characteristic is influenced by the family and community environment. ${ }^{49}$

From the exposure to the results of the interview, the authors conclude that the behavior of cursing students of State Senior High School 4 Poso, the development is estimated to reach more than 25 percent, the abusive behavior of course originates from the family and community environment and / or peers, thus it can this can be proven when they don't like what their friends say or when they get angry, they make swear words, such as dogs, pigs and others.

10. Likes to Say Bad Words

According to Suhendi, that the behavior of students in Poso 4 State

495t. Chadijah Badau dan Novita Andayani, Guru Mata Pelajaran Pendidikan Agama Islam Sekolah Menengah Atas Negeri 4 Poso, wawancara Penulis di Poso, 16 Desember 2019.
Senior High School has existed and developed since the family environment and there is a lack of family attention, especially parents who do not apply the rules that have been agreed upon and given since registering their children and their development is estimated at 20 percent. ${ }^{50}$ St. Chadijah Badau revealed that the development of the dirty talkative behavior of students at the State Senior High School 4 Poso reached 80 percent. Meanwhile, Novita Andayani revealed that the development can reach 25 percent, this trait is influenced by the family and community environment. ${ }^{51}$

From the exposure to the results of the interview, the authors conclude that the behavior of the students of State Senior High School 4 Poso has an estimated development of more than 25 percent, the dirty talk behavior of course originates from the family and community environment and / or their peers, which can it was proven when they were joking with their friends during recess, sometimes the dirty words were stamped by one of the students, which in the end the other friends also said it.

11. Likes to Fight

According to Suhendi, that the fighting behavior of students in Poso 4 State Senior High School has existed and

50Suhendi, Guru Mata Pelajaran Pendidikan Agama Islam Sekolah Menengah Atas Negeri 4 Poso, wawancara Penulis di Poso, 16 Desember 2019.

51St. Chadijah Badau dan Novita Andayani, Guru Mata Pelajaran Pendidikan Agama Islam Sekolah Menengah Atas Negeri 4 Poso, wawancara Penulis di Poso, 16 Desember 2019.

e-ISSN: 2715-4572

p-ISSN: 2716-1439 
developed since the family environment and the lack of attention and education of the family, especially parents who do not apply Islamic rules and have also agreed and given since registering their children and their development is estimated to reach 20 percent. ${ }^{52}$ St. Chadijah Badau revealed that the development of the fighting behavior of Poso 4 Senior High School students reached 30 percent. Meanwhile, Novita Andayani revealed that the development can reach 25 percent, this characteristic is influenced by the family and community environment. ${ }^{53}$

From the exposure to the results of the interview, the authors concluded that the fighting behavior of students at State Senior High School 4 Poso, its development is estimated to reach more than 25 percent, the fighting behavior of course starts from the family and community environment and / or their peers, which can be proven when An error occurs among fellow students or when their friends joke excessively, they end up having emotions that result in fights between students.

\section{Loves to Truant}

According to Suhendi, the truancy behavior of students in Poso 4 State Senior High School has existed and developed since the elementary or junior

52Suhendi, Guru Mata Pelajaran Pendidikan Agama Islam Sekolah Menengah Atas Negeri 4 Poso, wawancara Penulis di Poso, 16 Desember 2019.

53St. Chadijah Badau dan Novita Andayani, Guru Mata Pelajaran Pendidikan Agama Islam Sekolah Menengah Atas Negeri 4 Poso, wawancara Penulis di Poso, 16 Desember 2019. high school environment as well as the lack of family attention, especially parents who do not apply the rules that have been agreed upon and given since registering their children and their development is estimated to reach 20 percent. ${ }^{54}$ St. Chadijah Badau revealed that the development of truancy behavior of students in Poso 4 State Senior High School reached 60 percent. Meanwhile, Novita Andayani revealed that the development can reach 25 percent, this trait is influenced by the family and community environment. ${ }^{55}$

From the explanation of the results of the interview, the authors concluded that the truancy behavior of students at State Senior High School 4 Poso, its development is estimated to reach more than 25 percent, the truancy behavior of course originates from the elementary or junior high school environment and or its peers, thus it can it was proven when some of their friends entered learning and the teacher read attendance, it turned out that there were some students in each class who did not attend, especially if subjects or teachers they did not like entered teaching.

6. Disrespect to the Teachers

According to Suhendi, the behavior of disrespect for student

${ }^{54}$ Suhendi, Guru Mata Pelajaran Pendidikan Agama Islam Sekolah Menengah Atas Negeri 4 Poso, wawancara Penulis di Poso, 16 Desember 2019.

${ }^{55}$ St. Chadijah Badau dan Novita Andayani, Guru Mata Pelajaran Pendidikan Agama Islam Sekolah Menengah Atas Negeri 4 Poso, wawancara Penulis di Poso, 16 Desember 2019.

e-ISSN: 2715-4572

p-ISSN: 2716-1439 
teachers in Poso 4 State Senior High School has existed and developed since the family environment and there is a lack of family attention, especially parents who do not apply the rules that have been agreed upon and given since registering their children and their development is estimated at 40 percent. ${ }^{56}$ St. Chadijah Badau revealed that the development of behavior disrespect for the teachers of Poso 4 Public Senior High School students reached 60 percent. Meanwhile, Novita Andayani revealed that the development can reach 35 percent, this characteristic is influenced by the family and community environment. ${ }^{57}$

\section{Conclusion}

Based on the results of the discussion above, the authors conclude that the hedonistic behavior of students starts from consumptive, individualistic, selfish, lazy, irresponsible, extravagant, undisciplined in time, likes to lie, likes to play the guitar during study hours, likes to scream, likes to berate, likes to say dirty words, likes to fight, likes to disturb when friends are reading books, likes to throw garbage out of place, likes to poke at female friends when they pass, likes to skip classes, likes scribbling friends' books, disrespectful of teachers and others have existed and developed

\footnotetext{
56Suhendi, Guru Mata Pelajaran Pendidikan Agama Islam Sekolah Menengah Atas Negeri 4 Poso, wawancara Penulis di Poso, 16 Desember 2019.

57St. Chadijah Badau dan Novita Andayani, Guru Mata Pelajaran Pendidikan Agama Islam Sekolah Menengah Atas Negeri 4 Poso, wawancara Penulis di Poso, 16 Desember 2019.
}

since the family environment and a society where students socialize in everyday life and their development is very significant, that is very dangerous, because students do not want to be more happy with worldly life and forget about the afterlife that Allah has promised, and it is necessary to know that not all hedonistic behavior that's bad, but there's also hedonic behavior that is hasanah / good and is liked by Allah and His Messenger, including: people who have abundant assets but feel happy and joy when helping to alleviate the burden of suffering from their fellow humans and who feel happy and joy in studying.

\section{DAFTRA PUSTAKA}

Abdul Rahman, Jamal, Tahapan Mendidik Anak, Penerjemah: Bahrun Abu Bakar Ihsan Zubaidi, Bandung: Irsyad Baitus salam, 2008.

Ahmadi, Abu dan Nur Uhbiyati, Ilmu Pendidikan, Jakarta: Rineka Cipta, 2001.

Allang, H.M Sattu, Kesehatan Mental dan Terapi Islam, Makassar : Berkah Utami Makassar, 2006.

Ali, M. Nashir, Dasar-Dasar Ilmu Mendidik, Jakarta: Mutiara, 1982. Ali Khan, Shafique, Filsafat Pendidikan alGhazali, Bandung : Pustaka Setia, 2005.

Arifin, H. M., Hubungan Timbal Balik di dalam Pendidikan Agama, di Lingkungan Sekolah dan Keluarga, Jakarta: Bulan Bintang, 1975.

Arikunto, Suharsimi, Prosedur Penelitian Suatu Pendekatan Praktik, Jakarta: Rineka Cipta, 2003. 
Audi, Robert, The Cambridge Dictionary of Philosophy, New York: Cambridge University Press, 1999.

Anshari, Endang Saifuddin, Pokok-Pokok Pikiran tentang Islam, Jakarta: Usaha Interprise, 2006.

Anwar, Sumarsih, The Effectiveness of Learning System in The Madrasah Aliyah, Jakarta : Board for Religious Research and Development, 2010.

Bakry, H. Sam'un, Menggagas Ilmu Pendidikan Islam, Bandung : Pustaka Bani Quraisy, 2005.

Bungin, Burhan, Metodologi Penelitian Kualitatif (Aktualisasi Metodologis Kearah Ragam Varian Kontemporer), Jakarta: Rajawali Press, 2001.

Daradjat, Zakiah, et.al., Ilmu Pendidikan Islam, Jakarta: Bumi Aksara, 2000.

Darahim, Andarus, Strategi Pengasuhan dan Pendidikan Anak Sejak Dini, Jakarta : Direktur Jenderal Pendidikan Luar Sekolah dan Pemuda Departemen Pendidikan Nasional, 2004.

Daulay, Haidar Putra, Pendidikan Islam, Jakarta: Kencana Prenada Media Group, 2000.

Dewojati, Cahyaningrum, Wacana Hedonisme dalam Sastra Populer Indonesia, Yogyakarta: Pustaka Pelajar, 2010.

Emzir, Metodologi Penelitian Pendidikan, Kuantitatif dan Kualitatif, Jakarta: Raja Grafindo Persada, 2009.

Evita, Evita, Syahid, Ahmad, \& Nurdin, Nurdin. (2019). Understanding Students' Learning Outcomes
Differences Through the Application of the Market Place Activity Type of Cooperative Learning Model and the Application of Conventional Learning Models International Journal of Contemporary Islamic Education, 1(1), 67-85.

Fatimah, Enung, Psikologi Perkembangan (Perkembangan Peserta Didik), Bandung : Pustaka Setia, 2010.

Hamalik, Oemar, Perencanaan Pengajaran Berdasarkan Pendekatan Sistem, Jakarta: Bumi Aksara, 2002.

Hasbullah, Otonomi Pendidikan, Jakarta: Rajawali Pers, 2010.

Kurniati, Kurniati, Nurdin, Nurdin, \& Nurasmawati, Nurasmawati. (2020). Improving Students' Cognitive and Affective Domains Students through Fostering Teacher Development International Journal of Contemporary Islamic Education, 2(2), 56-70.

Langgulung, Hasan, Beberapa Pemikiran tentang Pendidikan Islam, Bandung : Alma'arif, 1980.

Muhaimin, Pengembangan Kurikulum Pendidikan Agama Islam, Jakarta: Raja Grafindo Persada, 2007.

Mujib, Abdul, Ilmu Pendidikan Islam, Jakarta : Kencana Prenada Media Group, 2008.

Naim, Ngainun, Menjadi Guru Inspiratif Memberdayakan dan Mengubah Jalan Hidup Siswa, Yogyakarta: Pustaka Pelajar, 2011.

Nazarudin, Manajemen Pembelajaran, Yogyakarta: Teras, 2007.

Nurdin, Nurdin, Stockdale, Rosemary, \& Scheepers, Helana. (2014a). 
Coordination and Cooperation in E-Government: An Indonesian Local E-Government Case The Electronic Journal of Information Systems in developing Countries, 61(3), 1-21.

Nurdin, Nurdin. (2018). Institutional Arrangements in E-Government Implementation and Use: A Case Study From Indonesian Local Government. International Journal of Electronic Government Research (IJEGR), 14(2), 44-63. doi: 10.4018/ijegr.2018040104

Nurdin, Nurdin, Stockdale, Rosemary, \& Scheepers, Helana. (2014b, 6-9 Jan. 2014). The Role of Social Actors in the Sustainability of EGovernment Implementation and Use: Experience from Indonesian Regencies. Paper presented at the System Sciences (HICSS), 2014 47th Hawaii International Conference on System Science.

Nurdin, Nurdin, \& Aratusa, Zana Chobita. (2020). Benchmarking level interactivity of Indonesia government university websites. TELKOMNIKA

Telecommunication, Computing, Electronics and Control, 18(2), 853859.

Parkinson, G.H.R. et al. (Eds.), $A n$ Encyclopedia of Philosophy, London Routledge, 1996.

Papalia, dkk., Human Development (8th ed.), Boston: McGraw-Hill, 2008.

Pramono, Wahyudi, Etika Membangun Masyarakat Islam Moderen, Yogyakarta:Graha Ilmu, 2007.

Prihatin, Eka, Manajemen Peserta Didik, Bandung: Alfabeta, 2011.
Rakhmat, Jalaluddin, Meraih Kebahagiaan, Bandung : Simbiosa Rekatama Media, 2004.

Ramayulis dan Samsul Nizar, Filsafat Pendidikan Islam, Jakarta: Kalam Mulia, 2009.

Ra'uf, Amrin, Shoppingsaurus, Yogyakarta: DIVA Press, 2009.

Rahardjo, W. dan Y.B. Silalahi, Perilaku Hedonisme pada Pria Metroseksual serta Pendekatan dan Strategi yang Digunakan untuk Mempengaruhinya, Jakarta: Universitas Gunadarma Pesat, 2007.

Ree, Jonathan \& J.O. Urmson, The Concise Encyclopedia of Western Philosophy, Routledge, London dan New York, 2005.

Rusli, R. (2020). The Role of Family in Preventing Social Conflict in Society From Islamic Perspectives. Hunafa: Jurnal Studia Islamika, 17(1), 108-122.

Rusli, R., Hasyim, M. S., \& Nurdin, N. (2021). A New Islamic Knowledge Production And Fatwa Rulings: How Indonesia's Young Muslim Scholars Interact With Online Sources. Journal of Indonesian Islam, 14(2), 499-518.

Salam, Burhanuddin, Etika Individual; Pola Dasar Filsafat Moral, Jakarta : Rineka Cipta, 2000.

Setiadi, J., Nugroho, Perilaku Konsumen: Konsep dan Implikasi untuk Strategi dan Penelitian Pemasaran, Jakarta : Kencana Prenada Media Group, 2008.

Suwondo, Tirto, Fujoshi, Hedonisme, dan Mentalitas Pelajar, Yogyakarta : e-ISSN: $2715-4572$ p-ISSN: 2716-1439 
Kementerian Pendidikan dan

Kebudayaan Balai Bahasa

Daerah Istimewa Yogyakarta, 2016.

Simpson, J.A. and E.S.C. Weiner, The

Oxford English Dictionary,

Oxford : Clarendon Press, 1989.

Susanto, Potret-Potret Gaya Hidup Metropolis, Jakarta: Kompas, 2003.

Sarwono. Psikologi Remaja, Jakarta : Raja Grafindo Persada, 2007.

Santrock, W., John, Adolescence : Perkembangan Remaja, Jakarta : Erlangga, 2007.

Sunarto dan Hartono, Perkembangan Peserta Didik, Jakarta: Rineka Cipta, 2002.

Sugiono, Metode Penelitian Pendidikan, Pendekatan Kualitatif, Kuantitatif RED, Bandung: Alfabeta, 2015.

Tafsir, Ahmad, Ilmu Pendidikan dalam Perspektif Islam, Bandung: Remaja Rosdakarya, 2010.

Trianto, Model-Model Pembelajaran Inovatif Berorietasi Konstruktivistik, Jakarta: Prestasi Pustaka, 2012.

Tim Reality, Kamus Terbaru Bahasa Indonesia, Surabaya: Reality Publisher, 2008.

Ulum, M. Samsul dan Triyo Supriyatno, Tarbiyah Qur'aniyah, Malang : UIN Press, 2006.

Walgito, Bimo, Psikologi Sosial, Yogyakarta: Andi Offset, 1987.

Yusuf, Tayar, Metodologi Pengajaran Agama dan Bahasa Arab, Jakarta: Raja Grafindo Persada, 2005. 